\title{
Celiac artery in New Zealand rabbit: Anatomical study of its origin and arrangement for experimental research and surgical practice ${ }^{1}$
}

\author{
Marcelo Abidu-Figueiredo ${ }^{*}$, Bárbara Xavier-Silva², Themis M. Cardinot ${ }^{3}$, \\ Márcio A. Babinski ${ }^{4}$ and Maurício A. Chagas ${ }^{4}$
}

\begin{abstract}
Abidu-Figueiredo M., Xavier-Silva B., Cardinot T.M., Babinski M.A. \& Chagas M.A. 2008. Celiac artery in New Zealand rabbit: Anatomical study of its origin and arrangement for experimental research and surgical practice. Pesquisa Veterinária Brasileira 28(5):237-240. Departamento de Anatomia Animal, Instituto de Biologia, Universidade Federal Rural do Rio de Janeiro, Seropédica, RJ 23890-000, Brazil. E-mail: marceloabidu@gmail.com

Rabbits have been used as an experimental model in many diseases and for the study of toxicology, pharmacology and surgery in many universities. However, some aspects of their macro anatomy need a more detailed description, especially the abdominal and pelvic arterial vascular system, which has a huge variability in distribution and trajectory. Thirty cadaveric adult New Zealand rabbits, 13 male and 17 female, with an average weight and rostrum-sacral length of $2.5 \mathrm{~kg}$ and $40 \mathrm{~cm}$, respectively, were used. The thoracic aorta was cannulated and the vascular system was filled with stained latex S-65. The celiac artery and its proximal branches were dissected and lengthened in order to evidence origin and proximal ramifications. The celiac artery emerged between the $12^{\text {th }}$ and $13^{\text {th }}$ thoracic vertebra in $11(36.7 \%)$ rabbits; at the level of the $13^{\text {th }}$ thoracic vertebra in $6(20 \%)$ rabbits; between the $13^{\text {th }}$ thoracic vertebra and the $1^{\text {st }}$ lumbar vertebra in $12(40 \%)$ rabbits; and at the level of the $1^{\text {st }}$ lumbar vertebra in only one (3.3\%) rabbit. The mean length of the celiac artery was $0.5 \mathrm{~cm}$. The celiac artery first branch was the lienal artery, the second branch was the left gastric artery and the hepatic artery arose from the left gastric artery in all the dissected rabbits. No relation was observed between the celiac artery length and the rostrum-sacral length in rabbits. The number of left gastric and lienal artery branches and the distribution of celiac artery origin are not gender dependent.
\end{abstract}

INDEX TERMS: Anatomy, vascular system, celiac artery, experimental model, New Zealand rabbit.

RESUMO.- [Artéria celíaca em coelhos Nova Zelândia: estudo anatômico de sua origem e arranjo para a pesquisa experimental e a prática cirúrgica.] Os coelhos têm sido usados como modelo experimental em diferen-

\footnotetext{
${ }^{1}$ Received on November 24, 2007.

Accepted for publication on April 10, 2008.

2 Departamento de Anatomia Animal, Instituto de Biologia, Universidade Federal Rural do Rio de Janeiro (UFRRJ), Seropédica, RJ 23890000, Brazil. *Corresponding author: marceloabidu@ gmail.com

${ }^{3}$ Laboratório de Emergências Clínicas (LIM-51), Universidade de São Paulo (USP), Av. Dr. Arnaldo 455, sala 3134, São Paulo, SP 01246-903, Brazil.

${ }^{4}$ Departamento de Morfologia, Instituto Biomédico, Universidade Federal Fluminense, Av. Hernani Mello 101, Niterói, RJ 24210-150, Brazil.
}

tes patologias e para estudos de toxicologia, farmacologia e cirurgia em várias universidades. Entretanto apesar de sua grande utilização, muitos aspectos de sua macroanatomia, em especial os que se referem ao sistema vascular arterial que irrigam as viscerais abdominopélvicas ainda carecem de uma descrição mais detalhada, pois os vasos arteriais apresentam grande variabilidade na sua distribuição e trajeto. Foram utilizados 30 coelhos, 13 machos e 17 fêmeas, pesando em media 2,5 $\mathrm{kg}$ e apresentando comprimento rostro-sacral em torno de $40 \mathrm{~cm}$. A artéria aorta torácica foi canulada e através da mesma foi feita à fixação com solução de formaldeído a $10 \%$ e repleções vasculares com solução de Petrolátex S65 corado. A artéria celíaca e suas ramificações 
proximais foram dissecadas ao longo do seu percurso, registrando com auxílio de um paquímetro seu comprimento e sua esqueletopia. A artéria celíaca teve sua emergência de forma única diretamente da artéria aorta abdominal em todos os animais dissecados. Emitiu inicialmente a artéria lienal e a seguir a artéria gástrica esquerda que se continuou como hepática em todos os 30 animais. A artéria celíaca teve sua origem entre a $12^{\mathrm{a}}$ e $13^{\mathrm{a}}$ vértebra torácica em 11 animais $(36,7 \%)$, na $13^{\text {a }}$ vértebra torácica em $6(20 \%)$, entre a $13^{\text {a }}$ vértebra torácica e a $1^{\text {a }}$ vértebra lombar em $12(40 \%)$ e na $1^{\text {a }}$ vértebra lombar em apenas 1 animal (3,3\%). O comprimento médio da artéria celíaca foi de $0,5 \mathrm{~cm}$. Não foi observada relação entre o comprimento da artéria celíaca e o comprimento rostro-sacral dos coelhos. O número de artérias gástricas esquerdas, ramificações principais da artéria lienal, bem como a origem da artéria celíaca independeram do sexo do animal.

TERMOS DE INDEXAÇÃO: Anatomia, sistema vascular, artéria celíaca, modelo experimental, coelho Nova Zelândia.

\section{INTRODUCTION}

The knowledge of anatomical variations is important for radiological and surgical procedures in humans and animals due to its practical and theoretical significance for experimental research and surgical practice in experimental and domestic animals (Swindle et al 1988, Krotscheck et al. 2007). Particular attention has been paid to the dissective or angiographical study of the visceral vessels because of the variations noticed among various animal species. Some authors have studied the celiac artery ramification in domestic animals showing that its organization is very variable (Sleight \& Thomford 1970, Abidu-Figueiredo et al. 2005).

Rabbits have been used as an experimental model in many diseases, such as: erectil dysfunction (Qiu et al. 2000, Maia et al. 2006), portal hypertension (Omanwar et al. 2004, Abraldes et al. 2006) and sepsis (Kang \& Kim 2006). Moreover, they have been used for the study of toxicology, pharmacology and surgery for the veterinary medicine course in many universities. However, some aspects of their macro anatomy need a more detailed description, especially the abdominal and pelvic arterial vascular system, which has a huge variability in distribution and trajectory.

For this reason, the aim of this study was to describe the celiac artery origin and arrangements in New Zealand rabbits to give morphological aid and support for experimental research and for the clinical, radiological and surgical practice of this animal.

\section{MATERIALS AND METHODS}

The UFRRJ Ethics Committee on Animal Research approved this study (No.23083.002379/2007). The anatomical dissections were performed in 30 fresh cadaveric adult New Zealand rabbits (Oryctolagus cuniculus), 13 males and 17 females, with an average weight and rostrum-sacral length of $2.5 \mathrm{~kg}$ and $40 \mathrm{~cm}$, respectively. All animals are originated from the surgery lessons and they had been donated to the animal anatomy department. The euthanasia was made by an endovenous overdose of sodium thiopenthal.

The rabbits were positioned in right lateral decubit and by thoracic incision their $6^{\text {th }}$ and $7^{\text {th }}$ ribs were removed. Their thoracic aortas were dissected in situ to be cannulated to wash their vascular systems with saline solution and to fix them with $10 \%$ formaldehyde. Then, their vascular systems were filled with red stained Petrolax S-65 (Duque de Caxias Refinery REDUC / Petrobrás, Duque de Caxias, Rio de Janeiro, Brazil) and all rabbits were put in $10 \%$ formaldehyde solution for 5 days. After that period, a midline abdominal incision was made to dissect the abdominal aorta immediately below the diaphragm until the emergency of the renal arteries. The celiac artery and its proximal branches were dissected in situ, lengthen and measured with a digital pachymeter (Starrett, Pinheirinho, Itu, São Paulo, Brazil)

\section{Statistical analysis}

The statistical analysis was made by the Qui-square $\left(\mathrm{X}^{2}\right)$ test, with a $5 \%$ level of significance, to test if the nullity hypothesis is true for the number of gastric arteries, the origin of celiac artery and the number of lienal artery main ramifications. The relation between the celiac artery length and rostrum-sacral length was calculated by the correlation coefficient " $r$ " varying between -1 and +1 , that is, $-1 \leq r \leq+1$.

\section{RESULTS}

The celiac artery, the first major ventral branch of the abdominal aorta, arose as an only one artery in all (100\%). dissected rabbits (Fig.1). This vessel arose between the $12^{\text {th }}$ and $13^{\text {th }}$ thoracic vertebra in $11(36.7 \%)$ animals (Fig.1A); between the $13^{\text {th }}$ thoracic vertebra and the $1^{\text {st }}$ lumbar vertebra in 12 (40\%) animals (Fig. 1B); at the level of the $13^{\text {th }}$ thoracic vertebra in six $(20 \%)$ animals (Fig. $\left.1 \mathrm{C}\right)$; and at the level of the $1^{\text {st }}$ lumbar vertebra in only one (3.3\%) animal (Fig.1D). The mean length of the celiac artery was $0.5 \mathrm{~cm}$.

In all $(100 \%)$ dissected rabbits the first branch of the celiac artery was the lienal artery, the second branch was
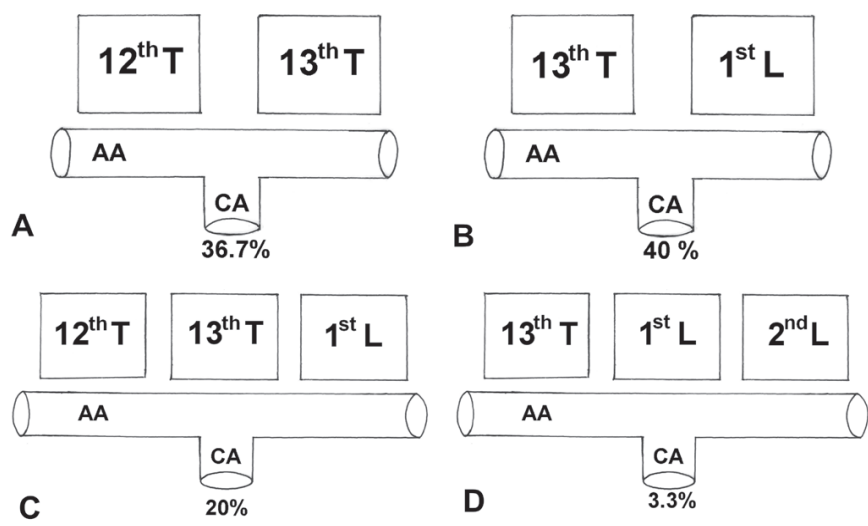

Fig.1. Schematic drawing of New Zealand rabbit celiac artery origin variation frequency (\%). $12^{\text {th }} \mathrm{T}=12^{\text {th }}$ thoracic vertebra, $13^{\text {th }} \mathbf{T}=13^{\text {th }}$ thoracic vertebra, $1^{\text {st }} \mathrm{L}=1^{\text {st }}$ lumbar vertebra, $2^{\text {nd }} \mathbf{L}=2^{\text {nd }}$ lumbar vertebra. 


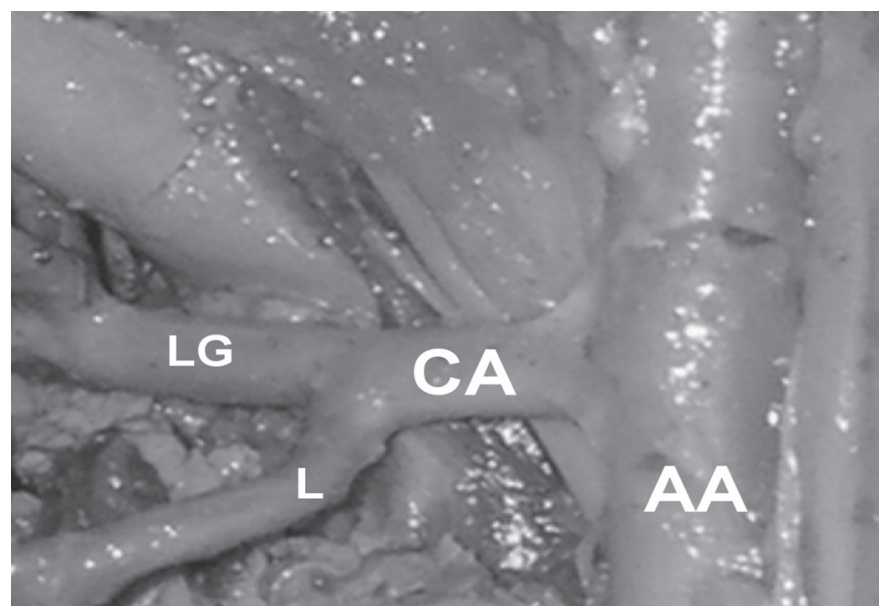

Fig.2. Celiac artery (CA) picture arising as an only one artery from the abdominal aorta (AA). The celiac artery first branch was the lienal artery $(\mathrm{L})$ and the second branch was the left gastric artery (LG).

the left gastric artery, and the hepatic artery arose from the left gastric artery (Fig.2). The lienal artery arose as an only one artery giving one artery with different numbers of branches to the spleen: one branch in 7 (23.3\%) animals, two branches in $7(23.3 \%)$ animals, three branches in 10 (33.3\%) animals, four branches in 4 (13.3\%) animals and five branches in $2(6.7 \%)$ animals. From the spleen, the lienal artery gave different numbers of branches to the stomach greater curvature: one branch in 7 (23.3\%) animals, two in $4(13.3 \%)$ animals, three in $5(16.7 \%)$ animals, four in $3(10 \%)$, and five in only $1(3.3 \%)$ animal.

The left gastric artery branches to the stomach were: five branches in $2(6.7 \%)$ animals, 4 in 10 (33.3\%) animals, three in $12(40 \%)$ animals and two in $6(20 \%)$ animals. In $23(76.7 \%)$ animals the left gastric artery bifurcated into the gastroduodenal and hepatic artery, in 5 (16.7\%) animals the left gastric artery bifurcated into the hepatic artery and another branch into the stomach lesser curvature, and in $2(6.7 \%)$ animals the left gastric artery ended into the liver as the hepatic artery. The hepatic artery arose from the left gastric artery and ended as an only one artery into the liver in all dissected rabbits.

\section{DISCUSSION}

Although many authors have already described the celiac artery and its branches in many animals, it still presents not described variations in rabbits. In our study, the celiac artery, the first major ventral branch of the abdominal aorta, arose as an only one artery in all the examined rabbits, supporting many authors descriptions about the celiac artery in mammals (Sleight \& Thomford 1970, Schmidt et al. 1980, Bednarova \& Malinovsky 1984, Abidu-Figueiredo et al. 2005) However, variations in the celiac artery arise have been reported in many mammals. In bubalines, the celiac artery arose at the level of the thoracic aorta (Machado et al. 2000). In caprines, the presence of a celiac-mesenteric trunk, formed by the celiac artery and cranial mesenteric artery, has been reported (Langenfeld \& Pastea 1977). In humans, there is also the presence of a celiac-mesenteric trunk formed by celiac artery and the superior mesenteric artery (Çiçekciba ${ }^{\circ} i$ et al. 2005). Still in humans, there is a rare incidence of a celiac-bimesenteric trunk formed by the celiac artery, superior mesenteric artery and inferior mesenteric artery (Bergman et al. 1988, Nonent et al. 2001).

Schwarze (1970) and Nickel et al. (1983) reported that the celiac artery arises at the level of the $17^{\text {th }}$ and $18^{\text {th }}$ thoracic vertebra in equines, at the level of the $1^{\text {st }}$ lumbar vertebra in bovines and carnivorous. However, AbiduFigueiredo (2005) showed that the celiac artery arises between the $1^{\text {st }}$ and $2^{\text {nd }}$ lumbar vertebra or at the level of the $2^{\text {nd }}$ lumbar vertebra in carnivorous. But, no data were found about rabbits until this moment. So, the present study reported that the celiac artery arose between the $12^{\text {th }}$ and $13^{\text {th }}$ thoracic vertebra in $11(36.7 \%)$ rabbits; at the level of the $13^{\text {th }}$ thoracic vertebra in $6(20 \%)$ rabbits; between the $13^{\text {th }}$ thoracic vertebra and the $1^{\text {st }}$ lumbar vertebra in 12 $(40 \%)$ rabbits; and at the level of the $1^{\text {st }}$ lumbar vertebra in only one $(3.3 \%)$ rabbit.

Our findings showed that the celiac artery first branch was the lienal artery. In accordance with Nickel et al. (1983), the lienal artery arises directly from the celiac artery in all domestic mammals. However, Schmidt et al. (1980) reported a rare variation that is the lienal artery arising from the cranial mesenteric artery in dogs. The lienal artery gave different number of branches.

In rabbits, our findings showed that the celiac artery second branch was the left gastric artery. In cats and dogs, Nickel et al. (1983) showed that the left gastric artery arises directly from the lienal artery, but this fact was not confirmed by Enge \& Flatmark (1972) and Abidu-Figueiredo et al. (2005). They showed that the left gastric artery arises from the celiac artery in dogs. In pigs, the left gastric artery arises directly from the lienal artery, while in horses and bovines the left gastric artery arises directly from the celiac artery. In ovines, the left gastric artery arises from the hepatic artery (Schwarze 1970, Nickel et al. 1983).

In carnivorous, bovines, swines and equines the hepatic artery arises directly from the celiac artery (Schwarze 1970, Nickel et al. 1983, Abidu-Figueiredo et al. 2005). However, in this study we observed that the hepatic artery is a branch of the left gastric artery in all the examined rabbits.

No relation was observed between the celiac artery length and the rostrum-sacral length in rabbits. The number of left gastric and lienal arteries branches and the distribution of celiac artery origin are not gender dependent. The knowledge of celiac artery variations in rabbits has practical and theoretical significance for experimental research and for the clinical, radiological and surgical practice of this animal.

\section{REFERENCES}

Abidu-Figueiredo M., Dias G.P, Cerutti S., Carvalho-De-Souza B., Maia R.S. \& Babinski M.A. 2005. Variations of celiac artery in dogs: anatomic 
study for experimental, surgical and radiological practice. Int. J. Morphol. 23:37-42.

Abraldes J.G., Pasarín M. \& García-Pagán J.C. 2006. Animal models of portal hypertension. World Gastroenterol. 12(41):6577-6584.

Bednarova Z. \& Malinovsky I. 1984. Ramification of celiac artery in the domestic cat. Folia Morphol. 34:36-44.

Bergman R.A., Thompson S.A., Afifi A.K. \& Saadeh F.A. 1988. Compendium of Human Anatomic Variation: Catalog, atlas and world literature. Urban and Schwarzenberg, Baltimore. 1000p.

Çiçekcibaôi A.E., Uysal I.I., Şeker M., Tuncer I., Buyukmumcu M. \& Salbacak A. 2005. A rare variation of the coeliac trunk. Ann. Anat. 187:387-391.

Enge I. \& Flatmark A. 1972. Selective celiac and hepatic artery angiography in normal dogs. Scand. J. Gastroenterol. 7:361-368.

Kang C.H. \& Kim W.G. 2006. The effect of vasopressin on organ blood flow in an endotoxin-induced rabbit shock model. J. Invest. Surg. 19(6):361-369.

Krotscheck U., Adin C.A., Hunt G.B., Kyles A.E. \& Erb H.N. 2007. Epidemiologic factors associated with the anatomic location of intrahepatic portosystemic shunts in dogs. Vet. Surg. 36(1):31-36.

Langenfeld M. \& Pastea E. 1977. Anatomical variants of the celiac artery in sheep with special reference to the celiomesenteric arterial trunk. Anat. Anz. 142:168-174.

Machado M.R.F., Miglino M.A. \& Cabral V.P 2000. Origin of celiac and cranial mesenteric arteries in buffaloes (Bubalus bubalis). Braz. J. Vet. Res. Anim. Sci. 37(2):125-129.
Maia R.S., Babinski M.A., Abidu-Figueiredo M., Chagas M.A., Costa W.S. \& Sampaio F.J.B. 2006. Concentration of elastic system fibers in the Corpus cavernosum, Corpus spongiosum, and Tunica albuginea in the rabbit penis. Int. J. Impot. Res. 18(2):121-125.

Nickel R., Schummer A. \& Seiferle E. 1983. The Anatomy of the Domestic Animals. 1.Aufl. Verlag Paul Parey, Berlin. 610p.

Nonent M., Larroche P., Forlodou P. \& Senecail B. 2001. Coeliacbimesenteric trunk, anatomic and radiologic description: case report. Radiol. 220:489-91.

Omanwar S., Rizvi M.R., Kathayat R., Sharma B.K., Pandey G.K., Alam M.A., Malhotra V. \& Sarin S.K. 2004. A rabbit model of non-cirrhotic portal hypertension by repeated injections of $E$. coli through indwelling cannulation of the gastrosplenic vein. Hepatobiliary Pancreat. Dis. Int. 3:417-422.

Qiu Y., Kraft P., Lombardi E. \& Clancy J. 2000. Rabbit Corpus cavernosum smooth muscle shows a different phosphodiesterase profile than human Corpus cavernosum. J. Urol. 164:882-886.

Schmidt S., Lohse C.L. \& Suter P.F. 1980. Branching patterns of the hepatic artery in the dog: Arteriographic and anatomic study. Am. J. Vet. Res. 41:1090-1097.

Schwarze E. 1970. Compendio de Anatomia Veterinária. Acribia, Zaragoza. 247p.

Sleight D.R. \& Thomford N.R. 1970. Gross anatomy of the blood supply and biliary drainage of the canine liver. Anat. Rec. 166:153-160.

Swindle M.M., Smith A.C. \& Hepburn B.J.S. 1988. Swine as models in experimental surgery. J. Invest. Surg. 1:65-79. 